\title{
Organization and Administration of Graduate Studies in Canadian Universities
}

\author{
EDWARD A. HOLDAWAY*
}

\begin{abstract}
Considerable concern exists in Canada, the United States, and some other western countries about the rates of non-completion of graduate programs and the increasing amount of time needed for completion. A 1990-91 study obtained information and opinions about graduate program practices from samples of department heads and experienced supervisors of graduate students in five Canadian universities. Aspects associated most with successful completion within the universities' time limits were high student motivation, appropriate supervision, careful selection of students, clear definition of research field, and a substantial period of full-time study. The most commonly mentioned reasons provided for non-completion were acceptance of employment prior to completion, inadequate supervision, financial constraints, ill-conceived projects, lack of motivation, and lack of ability.
\end{abstract}

\section{Résumé}

Au Canada, aux États-Unis, et dans certains pays occidentaux, on s'inquiète des taux de diplômation observés dans les programmes de deuxième et troisème cycles, et de l'augmentation de la durée des études. Une enquête portant sur ces questions a recueilli les opinions d'un échantillon de directeurs de département et de professeurs ayant des tâches de direction d'étudiants dans cinq universités canadiennes. Selon cette étude, les facteurs favorisant la diplômation dans les

* University of Alberta 
délais prévus par les universités sont une forte motivation de la part de l'étudiant, un encadrement approprié, une attention à la sélection des étudiants, une définition claire du champ de recherche et une période prolongée d'études à plein temps. Parmi les facteurs négatifs cités, notons la décision d'accepter un emploi avant la fin du programme, une encadrement inadéquat, des contraintes financières, des projets mal conçus, un manque de motivation, et des carences au niveau des habiletés.

This paper has two main purposes. First, it presents an overview of some issues and alternative approaches in the organization and administration of graduate studies in universities in Canada and other selected countries. Second, it presents the results of a survey of department heads/chairs/graduate coordinators and experienced graduate supervisors about practices and opinions related to organizational, administrative, and other relevant matters which have been identified in the literature or in discussions on campuses.

\section{Issues and Alternative Approaches}

Our current knowledge about the organization and administration of graduate programs is found in two main sources: (a) reports and periodicals (e.g., Canadian Association of Graduate Schools, Statistical Report 1991; and various publications of the Council of Graduate Schools); and (b) manuals of faculties of graduate studies. The information in these publications tends to be of three types: (a) statistical (e.g., enrolment data); (b) expressions of individual opinion; and (c) statements of policies and procedures. No publication exists which synthesizes policies, procedures, opinions, issues, completion rates, and completion times for graduate studies in Canadian universities collectively. Yeates (1992) has, however, recently provided a very useful document which includes Ontario data on these matters.

The last comprehensive examination of Canadian graduate studies was the Canada Council survey conducted by Healy, Dion, and Neatby (1978a \& 1978b). That report included these conclusions: (a) "Our experience as a Commission has also alerted us to the importance of research in the area of graduate studies," and (b) we are "woefully ignorant" of "the influence of socioeconomic factors on applications for admission to graduate studies" and "the factors affecting the time required to complete a degree" (1978a, p. 95). Several aspects of the organization and administration of graduate studies have received recent attention, as discussed below. Publications by the Royal Society of Canada (1989, 1991), OECD (1987), and the U.K. Economic and Social 
Research Council (1989a, 1989b, and 1991) attest to the seriousness with which concerns related to graduate studies are being addressed in several countries.

Following analyses of briefs, letters, discussions, and hearings, the University Research Committee of the Royal Society of Canada (1991) prepared 23 recommendations for consideration by governments, the granting councils, the universities, and the Association of Universities and Colleges of Canada. Those directly relevant to this paper are listed below:

12. the Canadian Association of Graduate Schools should propose guidelines to encourage high standards of supervision and speedier completion of programs of graduate study, particularly those leading to doctoral degrees. (p. 29)

13. the granting councils significantly increase the number and value of their doctoral and post-doctoral awards, over the next five years increasing expenditures by SSHRC from the present level of $\$ 25$ million to $\$ 57$ million; by NSERC from the present level of $\$ 65$ million to $\$ 100$ million; and by MRC from the present level of $\$ 20$ million to $\$ 36$ million. (p. 30 )

14. the Association of Universities and Colleges of Canada undertake the development of a national assessment guide to graduate programs in Canadian universities. (p. 31)

15. more concerted action be taken by universities to achieve greater collaboration in graduate programs and research, and that both levels of government provide initiatives to speed the process. (p. 32)

Malaney (1988), in his review of "graduate education as an area of research," drew these conclusions: (a) "There has been very little research related to the administration of graduate education" (p. 444); (b) most research related to graduate education is relatively recent and relates mostly to students; (c) the research methods usually involve questionnaires and analysis of students' records; (d) little systematic research has been conducted on graduate student retention; (e) little effort has been made to assess the value and potential of graduate assistantships; and (f) more research has been on doctoral programs than master's programs. He recommended these activities: (a) greater use of personal interviews-in research, (b) more aggregation of data and information across institutions, (c) study of the organizational placement of graduate schools and the effectiveness of various structures, and (d) more research on master's students. 
With respect to the importance of doctoral programs, Bowen and Rudenstine (1992) claimed that

doctoral education occupies a particularly critical place in the overall structure of higher education because it is the training ground for almost all those who become faculty members, as well as for many who pursue other vocations of broad import. (p. xv)

They also observed that graduate education "enjoys enormous prestige and yet it is relatively unexamined and not carefully monitored" and reported that they are aware "how hard it has been to obtain answers to even the most elementary questions concerning graduate education" (p. xv). In attempting to explain why "so little systematic study has been devoted to doctoral education in general," Bowen and Rudenstine (1992) proposed that "particularly daunting conceptual and empirical problems . . . bedevil study of graduate education." Their comments appear to be equally applicable to Canada.

\section{Current Knowledge}

Our current knowledge about the organization and administration of graduate studies can be categorized under headings (i)-(viii) below.

(i) Enrolment trends. Information about some trends is readily available from the Canadian Association of Graduate Schools (1991) and the Department of the Secretary of State (1990). In 1991, total doctoral enrolment in Canadian universities was 21,709 and total master's enrolment was 59,024, with full-time percentages being markedly different $-81.9 \%$ doctoral and $57.5 \%$ master's. Graduate enrolment has approximately doubled in 20 years.

(ii) Importance and purpose of graduate studies. Graduate education is acknowledged by experts in different countries to be extremely important for national and provincial development, production of highly qualified manpower, and scientific advancement (e.g., OECD, 1987, and Royal Society of Canada, 1991). Also, more employers are requiring graduate degrees. Gordon et al. (1990) therefore recommended that we need to be able to accommodate more part-time students, more working adults, more minorities, and more women in graduate programs (p. 1).

(iii) Place in university structure. Malaney (1988) concluded that schools/faculties of graduate studies are incorporated into university organizational structures in a variety of ways and that little is known about these structures and "their relative organizational effectiveness" (p. 444). This situation also applies to Canada. Although the role of graduate schools/faculties has been 
usefully described by Gordon et al. (1990, pp. 3-6), no comprehensive statement exists for Canadian universities collectively.

(iv) Completion rates and times of program completion. Data on these aspects are available for some jurisdictions and some disciplines (e.g., Yeates, 1991), but no overall Canadian data had been prepared. Expressions of concern are common in various countries about increasing length of time to complete a degree and the high percentages of non-completion (e.g., OECD, 1987; Dahllöf, 1989). Spurr (1970, p. 127) usefully termed these aspects "attrition" and "attenuation." The Canadian Association of Graduate Schools in 1987 expressed concerns over (a) the "excessive and increasing time" needed to finish the PhD in Canada and (b) the "alarming drop-out rate" (Graduate deans unhappy..., 1988). Similarly, Traugott et al. (1990) in a Council of Graduate Schools publication stated that "in recent years the total time required to complete the [PhD] degree has tended to expand. The reasons for this tendency need to be studied carefully and controlled where this is feasible" (p. 14). Cude (1991) has recently advocated that better statistics be made available about completion rates and completion times for doctoral students in Canadian universities.

Cude (1987) also stated that the $\mathrm{PhD}$ has become "a trap for the candidate and a sinkhole for intellectual resources," and that "inflexible, cumbersome, restrictive and deplorably wasteful" practices are used. In Australia, Moses (1985) observed that "full-time students take longer to complete their $\mathrm{PhD}$ than they ought to (in light of university guidelines and funding practices)" (p. 3), that science students complete more quickly than do humanities and social sciences students, and that attrition rates vary between $29 \%$ and $48 \%$.

For the United Kingdom, Winfield (1987b) observed that "the doctorate, though important, is also in urgent need of reform" (p. 15), and, after criticizing the length of time taken to complete the PhD, stated that most PhDs in the social sciences could be completed in four years. (This view was supported earlier by Spurr (1970, p. 132) for PhD degrees in the United States.) Winfield reported that a time-limited $\mathrm{PhD}$ is being discussed in many countries, notably the United States, France, Sweden, and the Netherlands.

Successful completion of the $\mathrm{PhD}$ within a reasonable time has been associated with the following variables: adequate motivation (OECD, 1987; Spurr, 1970); effective supervision (Winfield, 1987a; OECD, 1987; Powles, 1989); full-time study (OECD, 1987); selection and examinations (Task Force..., 1975); financial support (Canadian Association of Graduate Schools, 1987; OECD, 1987); department of study, ethnicity, citizenship, and gender (Zwick, 1991); and careful selection of topic and project (Hamilton et al., 1991, p. 20). 
For the University of Toronto, Sheinin (in Filteau, 1989) reported that (a) on average, $60 \%$ of male students who commence $\mathrm{PhD}$ programs attain the degree compared with $50 \%$ of female students, and (b) both men and women had the highest $\mathrm{PhD}$ graduation rate in the life sciences and the lowest in the humanities and social sciences. Yeates (1991) provided data which showed that $57.34 \%$ of the 1,172 doctoral students who commenced their studies in 10 Ontario universities in the fall of 1980 had obtained the degree in 10 or fewer years; $13 \%$ of the 1,172 commencing students withdrew in the first year. No information was provided by Yeates about whether any of these first-year withdrawals were later readmitted.

(v) Characteristics of graduate students. Little is known about the characteristics and opinions of Canadian graduate students. We do not have sufficient data about how Canadian graduate students finance their studies, how financial difficulties affect attrition and attenuation, and the effect of perceived financial problems upon enrolment of potential graduate students (Dagg, 1990). Several studies have identified the special problems of female students. For example, Wise (in Filteau, 1989) noted that many women are studying part-time, and that part-time students are not eligible for financial support. Powles (1986) found similar concerns in Australia. Another important aspect involves the characteristics and experiences of international students: they constituted $15.7 \%$ of all graduate students in Canadian universities in 1990, with the highest percentage being about $34 \%$ of all graduate students in science/engineering (Canadian Association of Graduate Schools, 1991).

(vi) Review practices. Reviews of graduate programs, which add to our knowledge (Wilson, 1987), are conducted by many Canadian universities (e.g., Alberta, Calgary, and McGill), but distribution of the reports of such reviews is usually restricted. The Ontario Council on Graduate Studies conducts a unique system of reviews of graduate programs in 15 autonomous universities (Yeates, n.d.; Stewart, 1988).

(vii) Theses. Boyer (1990) advocated that "the dissertation, or a comparable project, should continue to be the centerpiece-the intellectual culmination of the graduate experience" (pp. 73-74). The content of theses appears to be left largely to students and their advisory committees. Synthesized information about thesis practices in various programs in Canadian universities is not available. Matters such as length, extent of original contribution, sponsorship, classified research, ethics, joint authorship, and format need to be addressed (Traugott et al., 1990). Several U.S. graduate schools now accept groups of published research papers as an alternative. The nature of the $\mathrm{PhD}$ thesis was commonly 
addressed in the responses to the U.K. Economic and Social Research Council Survey (Smith, 1990). The Council of Graduate Schools (Norris, 1989), being concerned that the average time to complete a $\mathrm{PhD}$ is now 7 years compared with 5.5 years in the 1960 s, established a task force in 1989 to examine alternatives to the thesis and to assess whether the thesis is "still serving its original purpose of demonstrating the student's ability to carry out independent scholarship" (p. 1). After surveying staff in 46 United States and four Canadian universities, the Council of Graduate Schools (1991) produced a policy statement entitled The Role and Nature of the Doctoral Dissertation which contained these major conclusions: (a) "the doctoral dissertation...defines the essence of the PhD degree"; (b) graduate students in the sciences and engineering often work in research groups and may already have published some results before producing a thesis; (c) students and graduate deans are less satisfied with faculty as advisers than are the faculty themselves; (d) "disciplinary diversity affects all aspects of the role and nature of the doctoral dissertation"; and (e) "new sensitivity is called for in today's complex and changing research environment" (pp. 31-32).

(viii) Supervisory practices. Various reports (e.g., Christopherson, 1983; Connell, 1985; Kirkwood, 1985; Powles, 1988; Busch, 1985; and Council of Graduate Schools, 1990) have shown that supervisory practices vary by professor and discipline and that constant, thoughtful supervision is one of the keys to successful graduate program completion. These authors and others (e.g., OECD, 1987; Gordon et al., 1990) have identified desirable aspects of supervision. But we do not have any overview of supervisory approaches used in Canadian universities.

Many other relevant matters are raised in the literature, including (a) concern that graduate students usually do little teaching and that those who do teach are often ill-prepared (e.g., Boyer, 1990), (b) whether only certain appropriately qualified staff members - who may constitute the "graduate faculty" - should be allowed to supervise graduate students (e.g., Gordon et al., 1990), (c) consideration of the quality of graduate teaching and supervision in career decisions (e.g., Gordon et al., 1990), (d) whether dissertations should be publishable (e.g., Hamilton et al., 1991), (e) whether alternative doctorates should be offered (e.g., OECD, 1987; Ontario Council on Graduate Studies, 1990; Yeates, 1991); (f) whether appropriate physical facilities are available for graduate students (Traugott et al., 1990), (g) recognition that graduate program procedures vary among disciplines (Hamilton et al., 1991; Yeates, 1991), (h) publication of papers based on student's research (Council of Graduate Schools, 1990), 
(i) use of committees rather than a single supervisor (Bowen \& Rudenstine, 1991, p. 284), (j) how students' research topics are selected (Hamilton et al., 1991 ), and (k) consideration of the different characteristics of practice-oriented master's programs (usually non-thesis) and research-oriented master's programs (Palm et al., 1990).

\section{Conceptual Framework}

The basic systems model involving inputs, process, outputs, and feedback is probably the most useful and comprehensive approach for study of the organization and administration of graduate studies. Examples of relevant variables, which are mentioned in the literature and university calendars, are listed below:

Inputs - goals of graduate studies, admission requirements, characteristics of students, characteristics of supervisors, numbers of students, resources, research ethos, and financial support.

Process - administration/organization of graduate studies, program requirements (courses, research, examinations), supervisory practices, and formal and informal interactions.

Outputs - completion rates, numbers completing, quality of graduates, research performance, staff and student satisfaction, and university/department reputation.

Feedback - opinions about effectiveness, efficiency, issues, and trends; conclusions from formal graduate program review.

Because not all of these variables could be examined in any one study, emphasis was placed upon selected university inputs, processes, student outputs, and feedback.

\section{Methodology}

During 1991, a pilot study was conducted in order to obtain preliminary information about practices in and opinions about the organization and administration of graduate studies in Canadian universities. This study involved the sending of questionnaires to 109 department heads and 149 supervisors across a range of disciplines in five universities - Alberta, Dalhousie, McGill, Saskatchewan, and Toronto. Each graduate dean was asked to provide the names of 20 department heads and 30 experienced supervisors; McGill provided the names of 30 department heads and all of these were approached. The respective overall completion rates by the cut-off date were $86 \%$ and $75 \%$, with 94 and 112 respondents respectively; these rates were very high for a study of 
this type, indicating substantial interest in the topic. Table 1 shows the rates of return for each university, while Table 2 displays information about the department heads' units.

The questionnaires, which were constructed specially for this study, had two main sections: (a) practices involved in administration and organization of graduate programs; and (b) aspects which may increase successful completion of graduate programs. They were pilot-tested with former department heads and graduate students. With respect to practices, department heads were asked to provide information about current practices and emphasis on selected aspects, and the supervisors to provide opinions on both areas. Questionnaire items related to the following matters which have been identified as relevant either in the literature or in discussions at universities - purpose of graduate studies, course work requirements, involvement of faculty members, information provided to graduate students, facilities for graduate students, program quotas, admissions, nature of PhD thesis, master's non-thesis programs, supervisory committees, financial support, and examinations. A multiple-choice format was used for all questions. For most of the questions dealing with the existence of selected practices, department heads were provided with a "true-undecidedfalse" scale. However, for similar items, supervisors were asked to select from "agree-undecided-disagree" as such labels were deemed to be more appropriate for assessing attitudes.

Table 1

Response percentages for supervisors and department heads

\begin{tabular}{lccccccc}
\hline University & \multicolumn{3}{c}{ Supervisors } & & \multicolumn{3}{c}{ Department Heads } \\
\cline { 2 - 3 } \cline { 7 - 8 } & $\begin{array}{c}\text { Sample } \\
\mathrm{n}\end{array}$ & $\begin{array}{c}\text { Returned } \\
\mathrm{f}\end{array}$ & $\begin{array}{c}\text { Returned } \\
\% \mathrm{f}\end{array}$ & & $\begin{array}{c}\text { Sample } \\
\mathrm{n}\end{array}$ & $\begin{array}{c}\text { Returned } \\
\mathrm{f}\end{array}$ & $\begin{array}{c}\text { Returned } \\
\% \mathrm{f}\end{array}$ \\
\hline Alberta & 29 & 26 & 90 & & 18 & 18 & 100 \\
Dalhousie & 30 & 21 & 70 & & 21 & 19 & 90 \\
McGill & 30 & 22 & 73 & & 30 & 24 & 80 \\
Toronto & 30 & 18 & 60 & & 20 & 15 & 75 \\
Saskatchewan & 30 & 25 & 83 & & 20 & 18 & 90 \\
\hline TOTAL & 149 & 112 & 75 & 109 & 94 & 86 \\
\hline
\end{tabular}

Note: The responses from one supervisor and two department heads are not included in the analyses presented in Tables $2-6$. 
Table 2

Selected characteristics of department heads' departments ( $n=94$ )

\begin{tabular}{lccrrrrr} 
Discipline area & $\begin{array}{c}\text { Number of } \\
\text { department } \\
\text { heads responding }\end{array}$ & $\begin{array}{c}\text { Range of } \\
\text { number of } \\
\text { FTE staff }\end{array}$ & \multicolumn{2}{c}{$\begin{array}{c}\text { Range of numbers of students } \\
\text { Doctoral }\end{array}$} \\
\hline Humanities & 19 & $7-50$ & $2-87$ & $1-20$ & \multicolumn{1}{c}{ PT } & \multicolumn{1}{c}{ FT } & \multicolumn{1}{c}{ Paster's } \\
Life Sciences & 29 & $5-42$ & $3-55$ & $1-3$ & $3-63$ & $1-20$ \\
Science \& Engineering & 26 & $9-55$ & $6-101$ & $1-10$ & $2-73$ & $1-10$ \\
Social Sciences & 20 & $3-36$ & $1-50$ & $1-28$ & $4-114$ & $5-164$ \\
\hline
\end{tabular}

a The corresponding numbers of responding supervisors were 20,25, 39, and 26 .

b Some departments had no students in some of these categories.

For questions dealing with aspects related to successful completion, both department heads and supervisors chose a response from this scale: $1=$ not at all; $2=$ a little; $3=$ some extent; $4=$ considerable extent; and $5=$ a great deal. Department heads were asked to identify the extent to which they emphasized ten aspects which have been identified in the literature. Supervisors were asked to rate the extent to which they considered 15 aspects - the same ten as in the department heads' questionnaire as well as five others mainly related directly to students - contributed to successful completion.

Both groups were also asked for their opinions about why master's and doctoral students do not complete their programs within their university's time limits. About $90 \%$ provided these opinions. Additional comments relevant to the research questions were made by 66 respondents, and 67 gave suggestions about how the questionnaires could be improved.

The multiple-choice questions were analyzed using percentage frequency distributions for the groups overall and for sub-groups categorized by discipline orientation - humanities, life sciences, science and engineering, and social sciences. The free responses were content-analyzed.

\section{Results}

\section{Selected Practices}

Information about (a) the percentage frequency with which department heads identified the existence of selected practices and (b) the percentage frequency with which supervisors supported selected practices is presented below. 
Current situation. As shown in Table 3, the following 10 practices received at least $85 \%$ "true" responses and therefore could be considered as "normal practice": taking applicant's academic record into account in the admission decision (100\%); taking applicant's references into account in the admission decision (99\%); requiring course work of all master's students (99\%); making of the admission decision by Faculty of Graduate Studies on recommendation of department (99\%); holding final oral examinations for all doctoral students (99\%); trying to ensure that all full-time doctoral students receive some financial support $(90 \%)$; using a departmental admissions committee $(90 \%)$; requiring a "traditional" type of doctoral thesis $(89 \%)$; requiring course work of all doctoral students $(87 \%)$; and providing all full-time doctoral students with office and/or laboratory space $(85 \%)$. What could be called "common practice," i.e., those aspects which obtained "true" responses between $65 \%$ and $76 \%$, pertained to seven other aspects: enrolling doctoral students in a program jointly sponsored by another department (76\%); providing all full-time master's students with office and/or laboratory space (74\%); trying to ensure that all full-time master's students receive some financial support (74\%); varying the number of courses required depending on the student's background (71\%); holding candidacy examinations before doctoral students can progress to main part of thesis phase $(66 \%)$; encouraging doctoral students to take courses outside own department (65\%); and providing graduate students with a list of their responsibilities and duties $(65 \%)$. (The term "candidacy examinations" related to examinations and pertaining to change of status from "probationary candidate" to "candidate" - was not always understood by respondents.)

Some practices were uncommon in the universities sampled. High percentages of "false" responses were obtained for offering of practitioner doctoral degrees $(98 \%)$, establishment of a separate "graduate faculty" for especially meritorious faculty members $(81 \%)$, selection by master's students of optional non-thesis programs $(80 \%)$, establishment of quotas for high-demand graduate programs $(79 \%)$, holding final oral examinations for non-thesis master's students $(73 \%)$, and meeting the doctoral thesis requirement by submitting acceptable sets of (a) interrelated research reports (76\%), (b) interrelated articles published in refereed journals $(61 \%)$, and (c) unrelated articles published in refereed journals $(84 \%)$.

Opinions. As shown in Table 4, at least $85 \%$ of the supervisors agreed with the following propositions: the admission decision should take into account the applicant's academic record; the admission decision should take into account the applicant's references; course work should be required of all master's 
Practices involved in administration of graduate programs as identified by department heads ( $n=94$ )

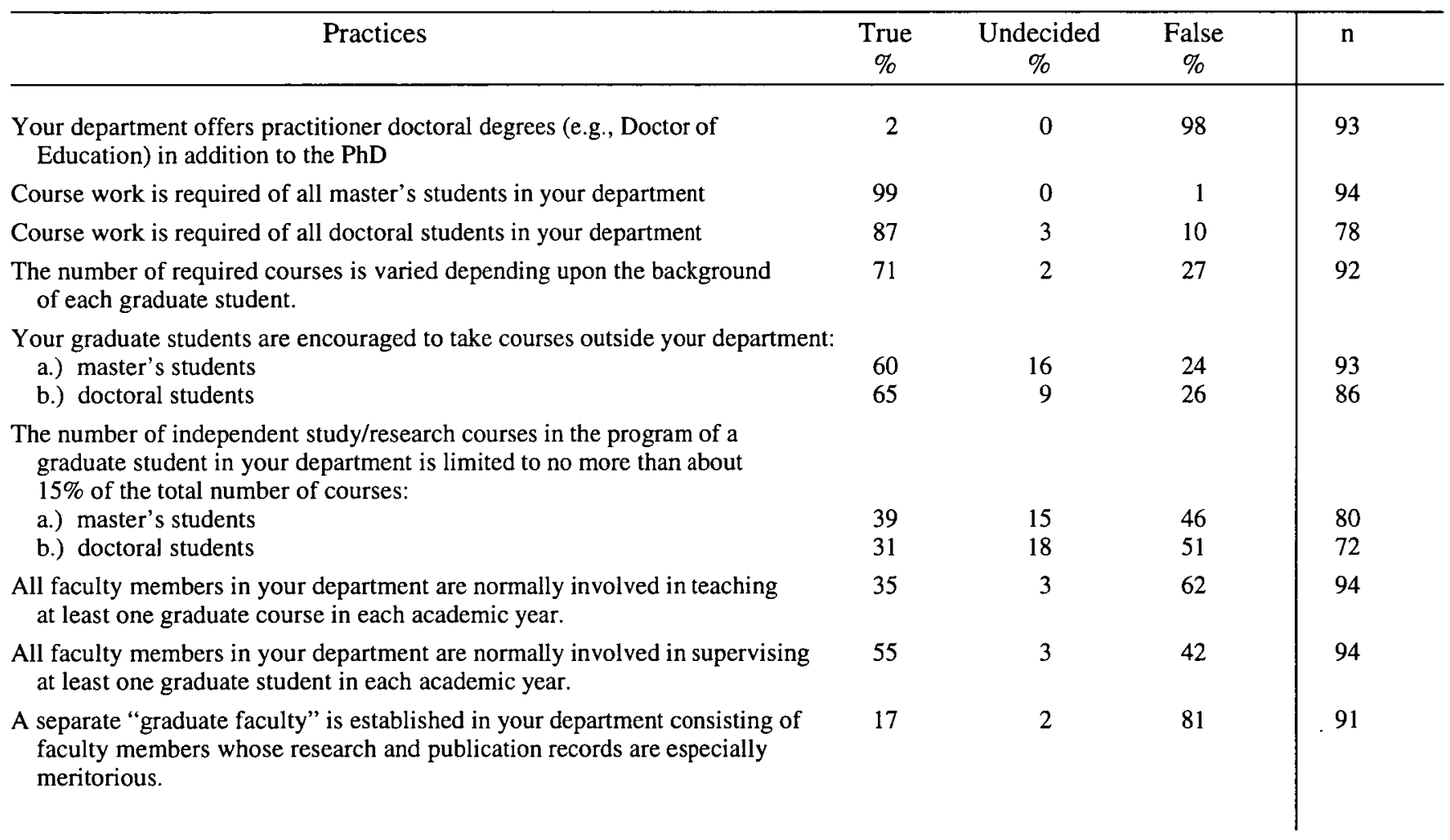


Table 3 (continued)

\begin{tabular}{|c|c|c|c|c|}
\hline Practices & $\begin{array}{c}\text { True } \\
\%\end{array}$ & $\begin{array}{l}\text { Undecided } \\
\qquad \%\end{array}$ & $\begin{array}{c}\text { False } \\
\%\end{array}$ & $\mathrm{n}$ \\
\hline $\begin{array}{l}\text { Your department provides your graduate students with a list of their } \\
\text { responsibilities and duties. }\end{array}$ & 65 & 11 & 25 & 93 \\
\hline \multicolumn{5}{|l|}{$\begin{array}{l}\text { All full-time graduate students in your department are provided with } \\
\text { appropriate office and/or laboratory space. }\end{array}$} \\
\hline $\begin{array}{l}\text { a.) master's students } \\
\text { b.) doctoral students }\end{array}$ & $\begin{array}{l}74 \\
85\end{array}$ & $\begin{array}{l}3 \\
2\end{array}$ & $\begin{array}{l}23 \\
13\end{array}$ & $\begin{array}{l}93 \\
85\end{array}$ \\
\hline $\begin{array}{l}\text { Your university has established quotas for your graduate programs where the } \\
\text { admission demand regularly exceeds the department's capacity. }\end{array}$ & 16 & 6 & 79 & 90 \\
\hline $\begin{array}{l}\text { The decision to admit an applicant to a graduate program is the responsibility } \\
\text { of the Faculty of Graduate Studies upon the recommendation of your } \\
\text { department. }\end{array}$ & 99 & 0 & 1 & 94 \\
\hline $\begin{array}{l}\text { Your department has established an Admissions Committee to deal with } \\
\text { applications from potential graduate students. }\end{array}$ & 90 & 1 & 9 & 86 \\
\hline \multicolumn{5}{|l|}{$\begin{array}{l}\text { The decision of your department to admit an applicant to graduate studies } \\
\text { takes into account: }\end{array}$} \\
\hline a.) applicant's academic record & 100 & 0 & 0 & 94 \\
\hline b.) applicant's references & 99 & 1 & 0 & 94 \\
\hline c.) applicant's work record & 60 & 13 & 27 & 90 \\
\hline d.) Miller's Analogies Test or Graduate Record Exam or equivalent & 37 & 7 & 56 & 84 \\
\hline
\end{tabular}




\begin{tabular}{|c|c|c|c|c|}
\hline Practices & $\begin{array}{c}\text { True } \\
\%\end{array}$ & $\begin{array}{l}\text { Undecided } \\
\%\end{array}$ & $\begin{array}{c}\text { False } \\
\%\end{array}$ & $\mathrm{n}$ \\
\hline $\begin{array}{l}\text { a.) The "traditional" type of doctoral thesis remains a requirement in } \\
\text { your discipline. }\end{array}$ & 89 & 1 & 9 & 85 \\
\hline $\begin{array}{l}\text { b.) The doctoral thesis requirement can be met in your discipline by } \\
\text { submission of an acceptable set of interrelated research reports. }\end{array}$ & 21 & 4 & 76 & 82 \\
\hline \multicolumn{5}{|l|}{$\begin{array}{l}\text { c.) The doctoral thesis requirement can be met in your discipline by } \\
\text { submission of an acceptable set of: }\end{array}$} \\
\hline i.) interrelated articles published in refereed journals & 29 & 10 & 61 & 82 \\
\hline ii.) unrelated articles published in refereed journals & 7 & 9 & 84 & 77 \\
\hline $\begin{array}{l}\text { When appropriate, your } \mathrm{PhD} \text { students can be enrolled in a program jointly } \\
\text { sponsored by another department, with one department having primary } \\
\text { administrative responsibility. }\end{array}$ & 76 & 5 & 20 & 86 \\
\hline $\begin{array}{l}\text { In your department, master's students are allowed to choose between a } \\
\text { thesis program and a non-thesis program. }\end{array}$ & 30 & 3 & 67 & 93 \\
\hline In your department, most master's students select a non-thesis program & 15 & 5 & 80 & 80 \\
\hline $\begin{array}{l}\text { In your discipline, the master's thesis has been eliminated and students' } \\
\text { research activity is concentrated mainly in the } \mathrm{PhD} \text { thesis. }\end{array}$ & 3 & 3 & 93 & 91 \\
\hline $\begin{array}{l}\text { In your department, any non-thesis program must include a signficant research } \\
\text { project. }\end{array}$ & 54 & 10 & 36 & 50 \\
\hline \multicolumn{5}{|l|}{$\begin{array}{l}\text { Supervisory committees in your department normally include a faculty member } \\
\text { from another department: }\end{array}$} \\
\hline a.) for master's students & 33 & 9 & 59 & 92 \\
\hline b.) for doctoral students & 54 & 8 & 38 & 85 \\
\hline $\begin{array}{l}\text { A list of responsibilities and duties of supervisory committees for graduate } \\
\text { students is provided by your department. }\end{array}$ & 63 & 4 & 32 & 93 \\
\hline
\end{tabular}




\begin{tabular}{|c|c|c|c|c|}
\hline Practices & $\begin{array}{c}\text { True } \\
\%\end{array}$ & $\begin{array}{l}\text { Undecided } \\
\qquad \%\end{array}$ & $\begin{array}{c}\text { False } \\
\%\end{array}$ & $\mathrm{n}$ \\
\hline \multicolumn{5}{|l|}{$\begin{array}{l}\text { Your department tries to ensure that all of its full-time graduate students } \\
\text { receive some financial support. }\end{array}$} \\
\hline a.) master's & 74 & 8 & 18 & 93 \\
\hline b.) doctoral & 90 & 0 & 10 & 87 \\
\hline \multicolumn{5}{|l|}{$\begin{array}{l}\text { Examinations are normally conducted at the end of every graduate course } \\
\text { in your department. }\end{array}$} \\
\hline a.) master's courses & 60 & 5 & 35 & 61 \\
\hline b.) doctoral courses & 56 & 7 & 37 & 87 \\
\hline \multicolumn{5}{|l|}{$\begin{array}{l}\text { Comprehensive examinations are normally conducted in your department } \\
\text { before graduate students can progress from the coursework phase to the } \\
\text { thesis-work phase of their programs. }\end{array}$} \\
\hline a.) master's program & 14 & 0 & 86 & 87 \\
\hline $\begin{array}{l}\text { Candidacy examinations are normally conducted before doctoral students can } \\
\text { progress towards the main part of the thesis phase of their programs in your } \\
\text { department. }\end{array}$ & 66 & 4 & 30 & 80 \\
\hline \multicolumn{5}{|l|}{$\begin{array}{l}\text { Final oral examinations are conducted by a faculty committee at the end of a } \\
\text { graduate student's program in your department. }\end{array}$} \\
\hline a.) non-thesis master's student & 19 & 8 & 73 & 52 \\
\hline b.) thesis master's student & 63 & 0 & 38 & 88 \\
\hline c.) doctoral student & 99 & 0 & 1 & 87 \\
\hline
\end{tabular}


Table 4

Attitudes of graduate supervisors towards selected practices related to graduate programs (n=112)

\begin{tabular}{|c|c|c|c|c|}
\hline Practices & $\begin{array}{l}\text { Agree } \\
\%\end{array}$ & $\begin{array}{l}\text { Undecided } \\
\qquad \%\end{array}$ & $\begin{array}{c}\text { Disagree } \\
\%\end{array}$ & $\mathbf{n}$ \\
\hline $\begin{array}{l}\text { Where resources permit, universities should offer practioner doctoral degrees } \\
\text { (e.g., Doctor of Engineering, Doctor of Education) in addition to the } \mathrm{PhD} \text {. }\end{array}$ & 36 & 38 & 25 & 107 \\
\hline Course work should be required of all master's students. & 97 & 2 & 1 & 111 \\
\hline Course work should be required of all doctoral students & 71 & 7 & 22 & 110 \\
\hline $\begin{array}{l}\text { The number of required courses should be varied depending upon the } \\
\text { background of each graduate student. }\end{array}$ & 85 & 5 & 11 & 110 \\
\hline \multicolumn{5}{|l|}{$\begin{array}{l}\text { Graduate students should be encouraged to take courses outside their own } \\
\text { department: }\end{array}$} \\
\hline a.) master's & 62 & 15 & 23 & 108 \\
\hline b.) doctoral & 75 & 9 & 17 & 106 \\
\hline \multicolumn{5}{|l|}{$\begin{array}{l}\text { The number of independent study/research courses in a graduate student's } \\
\text { program should be limited to no more than about } 15 \% \text { of the total number } \\
\text { of courses: }\end{array}$} \\
\hline a.) master's students & 44 & 20 & 36 & 103 \\
\hline b.) doctoral students & 30 & 19 & 51 & 102 \\
\hline $\begin{array}{l}\text { In departments with graduate programs, all faculty members should normally } \\
\text { be involved in teaching at least one graduate course in each academic year. }\end{array}$ & 29 & 7 & 64 & 108 \\
\hline $\begin{array}{l}\text { In departments with graduate programs, all faculty members should normally } \\
\text { be involved in supervising at least one graduate student in each academic year. }\end{array}$ & 34 & 5 & 61 & 110 \\
\hline $\begin{array}{l}\text { A separate "graduate faculty" should be established consisting of faculty } \\
\text { members whose research and publication records are especially meritorious. }\end{array}$ & 36 & 17 & 47 & 110 \\
\hline
\end{tabular}
background of each graduate student

department

a.) master's

b.) doctoral

62

The number of independent study/research courses in a graduate student's program should be limited to no more than about $15 \%$ of the total number of courses:

a.) master's students

departments with graduate programs, all faculty members should normally be involved in teaching at least one graduate course in each academic year. separate "graduate faculty" should be established consisting of faculty members whose research and publication records are especially meritorious. 
Table 4 (continued)

\begin{tabular}{|c|c|c|c|c|}
\hline Practices & $\underset{\%}{\text { Agree }}$ & $\begin{array}{l}\text { Undecided } \\
\%\end{array}$ & $\begin{array}{l}\text { Disagree } \\
\%\end{array}$ & $n$ \\
\hline $\begin{array}{l}\text { Universities should provide their graduate students with a list of their } \\
\text { responsibilities and duties. }\end{array}$ & 79 & 10 & 11 & 108 \\
\hline $\begin{array}{l}\text { All full-time graduate students should be provided with appropriate office } \\
\text { and/or laboratory space. } \\
\text { a.) master's students } \\
\text { b.) doctoral students }\end{array}$ & $\begin{array}{l}81 \\
94\end{array}$ & $\begin{array}{l}5 \\
3\end{array}$ & $\begin{array}{r}14 \\
4\end{array}$ & $\begin{array}{l}111 \\
111\end{array}$ \\
\hline $\begin{array}{l}\text { Universities should establish quotas for those graduate programs where the } \\
\text { admission demand regularly exceeds the department's capacity. }\end{array}$ & 64 & 14 & 22 & 107 \\
\hline $\begin{array}{l}\text { The decision to admit an applicant to a graduate program should be the } \\
\text { responsibility of the Faculty of Graduate Studies upon the recommendation } \\
\text { of the department. }\end{array}$ & 91 & 1 & 8 & 110 \\
\hline $\begin{array}{l}\text { Each department should establish an Admissions Committee to deal with } \\
\text { applications from potential graduate students. }\end{array}$ & 87 & 6 & 6 & 110 \\
\hline $\begin{array}{l}\text { The admission decision to graduate studies should take into account: } \\
\text { a.) applicant's academic record } \\
\text { b.) applicant's references } \\
\text { c.) applicant's work record } \\
\text { d.) Miller's Analogies Test or Graduate Record Exam or equivalent }\end{array}$ & $\begin{array}{r}100 \\
99 \\
73 \\
32\end{array}$ & $\begin{array}{r}0 \\
0 \\
18 \\
41\end{array}$ & $\begin{array}{r}0 \\
1 \\
9 \\
27\end{array}$ & $\begin{array}{l}112 \\
110 \\
104 \\
105\end{array}$ \\
\hline
\end{tabular}




\begin{tabular}{|c|c|c|c|c|}
\hline Practices & $\underset{\%}{\text { Agree }}$ & $\begin{array}{l}\text { Undecided } \\
\%\end{array}$ & $\begin{array}{l}\text { Disagree } \\
\%\end{array}$ & n \\
\hline $\begin{array}{l}\text { a.) The "traditional" type of doctoral thesis should remain a requirement in } \\
\text { your discipline. }\end{array}$ & 76 & 9 & 15 & 108 \\
\hline $\begin{array}{l}\text { b.) The doctoral thesis requirement could be met in your discipline by } \\
\text { submission of an acceptable set of interrelated research reports. }\end{array}$ & 31 & 14 & 55 & 106 \\
\hline \multicolumn{5}{|l|}{$\begin{array}{l}\text { c.) The doctoral thesis requirement could be met in your discipline by } \\
\text { submission of an acceptable set of: }\end{array}$} \\
\hline i.) interrelated articles published in refereed journals & 51 & 12 & 37 & 107 \\
\hline ii.) unrelated articles published in refereed journals & 12 & 18 & 70 & 108 \\
\hline $\begin{array}{l}\text { When appropriate, PhD students could be enrolled in a program jointly } \\
\text { sponsored by two departments, with one department having primary } \\
\text { administrative responsibility. }\end{array}$ & 93 & 4 & 4 & 110 \\
\hline $\begin{array}{l}\text { In your discipline, master's students should be allowed to choose between a } \\
\text { thesis program and a non-thesis program. }\end{array}$ & 42 & 9 & 49 & 111 \\
\hline $\begin{array}{l}\text { In your discipline, the objective of the master's degree would best be met } \\
\text { by a non-thesis program }\end{array}$ & 19 & 12 & 79 & 107 \\
\hline $\begin{array}{l}\text { In your discipline, the master's thesis should be eliminated and students' } \\
\text { research activity should be concentrated mainly in the PhD thesis. }\end{array}$ & 15 & 8 & 77 & 111 \\
\hline $\begin{array}{l}\text { In your discipline, any non-thesis program should include a signficant research } \\
\text { project. }\end{array}$ & 69 & 16 & 15 & 100 \\
\hline \multicolumn{5}{|l|}{$\begin{array}{l}\text { Supervisory committees should normally be required to include a faculty member } \\
\text { from another department: }\end{array}$} \\
\hline $\begin{array}{l}\text { a.) for master's students } \\
\text { b.) for doctoral students }\end{array}$ & $\begin{array}{l}21 \\
54\end{array}$ & $\begin{array}{r}13 \\
9\end{array}$ & $\begin{array}{l}66 \\
37\end{array}$ & $\begin{array}{l}110 \\
111\end{array}$ \\
\hline
\end{tabular}




\begin{tabular}{|c|c|c|c|c|}
\hline Practices & $\begin{array}{l}\text { Agree } \\
\%\end{array}$ & $\begin{array}{l}\text { Undecided } \\
\qquad \%\end{array}$ & $\begin{array}{c}\text { Disagree } \\
\%\end{array}$ & $\mathbf{n}$ \\
\hline $\begin{array}{l}\text { A list of the responsibilities and duties of supervisory committees for } \\
\text { graduate students should be provided by your university. }\end{array}$ & 84 & 6 & 10 & 108 \\
\hline \multicolumn{5}{|l|}{$\begin{array}{l}\text { Your department should try to ensure that all of its full-time graduate } \\
\text { students receive some financial support. }\end{array}$} \\
\hline b.) doctoral & 89 & 2 & 9 & 109 \\
\hline \multicolumn{5}{|l|}{$\begin{array}{l}\text { Examinations should normally be conducted at the end of every graduate } \\
\text { course. }\end{array}$} \\
\hline a.) master's courses & 56 & 13 & 31 & 108 \\
\hline b.) doctoral courses & 50 & 15 & 36 & 109 \\
\hline \multicolumn{5}{|l|}{$\begin{array}{l}\text { Comprehensive examinations should normally be conducted before graduate } \\
\text { students can progress from the course-work phase to the thesis-work phase } \\
\text { of their programs. }\end{array}$} \\
\hline a.) master's program & 20 & 11 & 69 & 107 \\
\hline b.) doctoral program & 62 & 6 & 31 & 109 \\
\hline $\begin{array}{l}\text { Candidacy examinations should normally be conducted before doctoral } \\
\text { students can progress towards the main part of the thesis phase of their } \\
\text { programs. }\end{array}$ & 60 & 15 & 25 & 106 \\
\hline \multicolumn{5}{|l|}{$\begin{array}{l}\text { Final oral examinations should be conducted by a faculty committee at the end } \\
\text { of a graduate student's program: }\end{array}$} \\
\hline a.) non-thesis master's student & 29 & 19 & 52 & 96 \\
\hline b.) thesis master's student & 69 & 6 & 26 & 108 \\
\hline c.) doctoral student & 92 & 3 & 5 & 110 \\
\hline
\end{tabular}


students; all full-time doctoral students should be provided with appropriate office and/or laboratory space; doctoral students could be enrolled in a program jointly sponsored by two departments; final oral examinations should be held for doctoral students; the Faculty of Graduate Studies should be responsible for admission of students on the recommendation of a department; and each department should have an admissions committee.

Comparison. Substantially more support was obtained for the following practices than was obtained for the extent to which they currently exist as assessed by "true" responses of department heads: (a) universities should offer practitioner doctoral degrees in addition to the $\mathrm{PhD}(36 \%$ agree vs. $2 \%$ currently exists), and (b) universities should establish quotas for high-demand graduate programs (64\% vs. $16 \%$ ). Somewhat more support was obtained for these two practices: (a) establishment of a separate graduate faculty for especially meritorious faculty members ( $36 \%$ agree vs. $17 \%$ currently exists), and (b) the doctoral thesis requirement could be met by an acceptable set of interrelated articles published in refereed journals ( $51 \%$ vs. $29 \%$ ).

\section{Emphasis on Selected Aspects}

This section includes information about (a) the percentage frequency of responses of department heads concerning the extent to which they have emphasized selected aspects - related to admission, program reviews, students, supervision, funding, etc. - in an attempt to increase successful completion of graduate programs, and (b) the percentage frequency with which supervisors supported these selected aspects. The reported means were based on this response scale: $1=$ not at all; $2=$ a little; $3=$ some extent; $4=$ considerable extent; and $5=$ a great deal.

Current situation. Table 5 presents the means and standard deviations for the responses of department heads. Two major results were obtained. First, the means for actions taken with respect to doctoral students were all higher than were those for master's students, possibly indicating greater attention to the doctoral sector. Second, the means for careful selection of students (master's 4.15; doctoral 4.30 ), appropriate supervision $(4.12 ; 4.19)$ and clear definition by students of research field $(3.84 ; 4.13)$ were somewhat higher than the other means, which ranged from 3.06 to 3.76 (master's) and 3.13 to 4.01 (doctoral). A substantial period of full-time study was also emphasized (3.76 and 4.00), while adequate financial support obtained a doctoral mean of 4.01 .

Opinions. The means and standard deviations of the responses of supervisors about the 15 practices are shown in Table 6 . Again the means pertinent to doctoral students were higher than those for master's students. The highest 
Table 5

Ratings by department heads of extent of emphasis placed upon selected aspects to increase successful completion of graduate programs $(n=94)$

\begin{tabular}{|c|c|c|c|c|c|c|}
\hline \multirow[t]{2}{*}{ Aspect } & \multicolumn{2}{|c|}{ Mean } & \multicolumn{2}{|c|}{$\mathrm{SD}$} & \multicolumn{2}{|c|}{$\mathrm{n}$} \\
\hline & Master's & $\overline{\text { Doctorate }}$ & Master's & Doctorate & $\overline{\mathrm{M}}$ & $\mathrm{D}$ \\
\hline $\begin{array}{l}\text { Increased admission } \\
\text { standards }\end{array}$ & 3.29 & 3.45 & 1.16 & 1.20 & 89 & 82 \\
\hline $\begin{array}{c}\text { Regular program reviews } \\
\text { (e.g., every } 3-5 \text { years) }\end{array}$ & 3.42 & 3.45 & 1.18 & 1.18 & 88 & 80 \\
\hline High student motivation & 3.57 & 3.66 & 1.05 & 1.04 & 86 & 80 \\
\hline Appropriate supervision & 4.12 & 4.19 & 0.77 & 0.70 & 87 & 84 \\
\hline $\begin{array}{l}\text { Substantial period of } \\
\text { full-time study }\end{array}$ & 3.76 & 4.00 & 1.30 & 1.18 & 84 & 79 \\
\hline $\begin{array}{l}\text { Careful selection of } \\
\text { students }\end{array}$ & 4.15 & 4.30 & 0.80 & 0.75 & 91 & 83 \\
\hline $\begin{array}{l}\text { Careful testing } \\
\text { throughout the program }\end{array}$ & 3.10 & 3.30 & 1.19 & 1.11 & 87 & 81 \\
\hline Adequate financial support & rt 3.61 & 4.01 & 1.13 & 1.01 & 90 & 83 \\
\hline $\begin{array}{l}\text { High problem-orientation } \\
\text { of students }\end{array}$ & 3.06 & 3.13 & 1.15 & 1.23 & 67 & 63 \\
\hline $\begin{array}{l}\text { Clear definition by } \\
\text { students of research field }\end{array}$ & 3.84 & 4.13 & 1.00 & 0.86 & 88 & 85 \\
\hline
\end{tabular}

Note: Calculation of means was based on responses using this scale:

$1=$ not at all; $2=\mathrm{a}$ little; $3=$ some extent; $4=$ considerable extent; $5=$ a great deal

means were obtained for high student motivation (master's 4.59; doctoral 4.66), appropriate supervision $(4.34 ; 4.35)$, and careful selection of students (4.21; 4.33). Other doctoral means higher than 4 , which indicated a considerable extent, were recorded for clear definition by students of research field (4.28), mental resilience of students (4.14), confidence of students (4.12), and a substantial period of full-time study (4.03). In contrast, the lowest means were associated with regular program reviews ( 2.59 master's; 2.70 doctoral), careful testing throughout the program $(2.86 ; 2.92)$, specification of a maximum period for program completion $(2.99,3.00)$, and encouragement from family members $(3.16 ; 3.18)$. 
Table 6

Ratings by supervisors of extent to which selected aspects contribute to successful completion of graduate programs $(n=112)$

\begin{tabular}{|c|c|c|c|c|c|c|}
\hline \multirow[t]{2}{*}{ Aspect } & \multicolumn{2}{|c|}{ Mean } & \multicolumn{2}{|c|}{ SD } & \multicolumn{2}{|c|}{$\mathrm{n}$} \\
\hline & Master's & Doctorate & Master's & Doctorate & $\mathbf{M}$ & $\mathrm{D}$ \\
\hline $\begin{array}{l}\text { Increased admission } \\
\text { standards }\end{array}$ & 3.56 & 3.72 & 1.17 & 1.16 & 105 & 105 \\
\hline $\begin{array}{l}\text { Regular program reviews } \\
\text { (e.g., every 3-5 years) }\end{array}$ & 2.59 & 2.70 & 1.09 & 1.09 & 107 & 108 \\
\hline High student motivation & 4.59 & 4.66 & 0.61 & 0.53 & 110 & 110 \\
\hline Appropriate supervision & 4.34 & 4.35 & 0.76 & 0.70 & 110 & 110 \\
\hline $\begin{array}{l}\text { Substantial period of } \\
\text { full-time study }\end{array}$ & 3.83 & 4.03 & 1.07 & 1.02 & 104 & 103 \\
\hline $\begin{array}{l}\text { Careful selection of } \\
\text { students }\end{array}$ & 4.21 & 4.33 & 0.85 & 0.82 & 108 & 108 \\
\hline $\begin{array}{l}\text { Careful testing } \\
\text { throughout the program }\end{array}$ & 2.86 & 2.92 & 1.05 & 1.11 & 106 & 105 \\
\hline Adequate financial support & rt 3.66 & 3.91 & 1.04 & 1.01 & 110 & 110 \\
\hline $\begin{array}{l}\text { High problem-orientation } \\
\text { of students }\end{array}$ & 3.71 & 3.99 & 0.98 & 0.97 & 88 & 88 \\
\hline $\begin{array}{l}\text { Clear definition by } \\
\text { students of research field }\end{array}$ & $\mathrm{d}^{3.87}$ & 4.28 & 0.97 & 0.79 & 104 & 105 \\
\hline $\begin{array}{l}\text { Encouragement of students } \\
\text { from family members }\end{array}$ & ts 3.16 & 3.18 & 1.06 & 1.12 & 103 & 103 \\
\hline $\begin{array}{l}\text { Mental resilience of } \\
\text { students }\end{array}$ & 3.89 & 4.14 & 0.85 & 0.83 & 104 & 104 \\
\hline Confidence of students & 3.91 & 4.12 & 0.85 & 0.83 & 107 & 107 \\
\hline $\begin{array}{l}\text { Favorable opinion of } \\
\text { students by supervisors }\end{array}$ & 3.48 & 3.66 & 0.92 & 0.90 & 108 & 108 \\
\hline $\begin{array}{l}\text { Specification of a } \\
\text { maximum period for } \\
\text { completion of program }\end{array}$ & 2.99 & 3.00 & 1.08 & 1.08 & 109 & 109 \\
\hline
\end{tabular}

Note: Calculation of means was based on responses using this scale:

$1=$ not at all; $2=$ a little; $3=$ some extent; $4=$ considerable extent; $5=$ a great deal 
Comparison. When the means for the ten common aspects in Tables 5 and 6 were compared, on only two aspects were the perceived means greater than the actual means. Supervisors' responses for high student motivation as a contributor obtained means of 4.59 (master's) and 4.66 (doctoral) as compared with 3.57 and 3.66 for department heads, while the corresponding figures for high problem-orientation of students were 3.71 and 3.99 compared with 3.06 and 3.13. (Several respondents stated that the term "high problem-orientation" was not clear.) Conversely, whereas regular program reviews had means of 3.42 (master's) and 3.45 (doctoral) with respect to emphasis placed by department heads to increase successful completion, supervisors rated this practice lowest with means of 2.59 and 2.70 .

\section{Reasons for Non-completion Within Time Limit}

Both department heads and supervisors were asked to provide "the three most common reasons why your graduate students do not complete their programs within your university's time limit." Separate responses were requested for master's and doctoral students. Replies were received from 84 department heads and 110 supervisors: these were combined and the most frequent replies are displayed in Table 7. Some replied that non-completion either did not occur or was rare in their departments. Others supplied either one or two reasons for master's and/or doctoral students, rather than three.

As shown in Table 7, the six reasons which received at least 25 mentions for master's students were as follows: accept employment prior to program completion; financial constraints; inadequate supervision; lack of motivation, etc.; lack of ability; and an ill-conceived research project. All except lack of ability were also in the six most frequently mentioned reasons relevant to doctoral students. These reasons are consistent with those identified in the literature cited earlier (e.g., Canadian Association of Graduate Schools, 1987; OECD, 1987; Powles, 1989; Hamilton et al., 1991; ). The frequencies for the reasons listed in Table 7 were very similar for the two degree levels, with the most striking differences between the replies for master's and doctoral students being substantially more frequency of mention for doctoral students of lack of incentive to complete on time ( 22 doctoral vs. 8 masters), discouragement during research activity (14 vs. 4 ), and difficulties with research project (12 vs. 2 ).

\section{Discipline Differences}

Space does not permit the inclusion of analyses of answers to all questions for respondents classified by discipline area. The following examples are included to demonstrate that discipline differences appear to exist among supervisors, 
Table 7

Frequency distributions of reasons provided by department heads and supervisors why graduate students do not complete programs within the university's time limit

\begin{tabular}{lcc}
\hline Reason & $\begin{array}{c}\text { Master's } \\
\text { Students } \\
\text { f }\end{array}$ & $\begin{array}{c}\text { Doctoral } \\
\text { Students } \\
\text { f }\end{array}$ \\
\hline Accept employment prior to program completion & 55 & 53 \\
Financial constraints & 37 & 45 \\
Inadequate supervision & 36 & 45 \\
Ill-conceived research project & 25 & 32 \\
Lack of motivation/commitment/resolve/ & 36 & 26 \\
$\quad$ work ethic/industry & 8 & \\
Lack of incentive to complete on time & 31 & 22 \\
Lack of ability & 23 & 20 \\
Personal difficulties, including health & 20 & 19 \\
Family reasons including marriage, pregnancy & & 19 \\
$\quad$ and change of location & 15 & \\
Overly ambitious research plans of student & 4 & 18 \\
Discouragement during research activity & 15 & 14 \\
Emergence of other interests & 14 & 12 \\
Changes of goals, e.g., transfer to Medicine & 11 & 12 \\
Demands of part-time work & 2 & 12 \\
Difficulties with research project & 17 & 6 \\
Inadequate preparation & & \\
\hline
\end{tabular}

even though the sub-samples were quite small. Life science respondents showed less agreement with the position that course work should be required of all doctoral students than did respondents in the three other discipline areas $-56 \%$ agreed compared with $66 \%$ (engineering and science), $89 \%$ (humanities), and $77 \%$ (social sciences). Also, the social science and life science supervisors agreed to a greater extent with the position that the number of required courses should be varied depending upon the student's background than did respondents for engineering/science and humanities $-100 \%$ and $96 \%$ vs. $74 \%$ and $68 \%$.

Some substantial differences also were found among the responses of the department heads concerning actual practices. For example, when asked 
whether the number of required courses varied depending upon the student's background, the following percentages answered "true" for the different disciplines - life science (83\%), engineering and science $(76 \%)$, social sciences $(63 \%)$, and humanities (53\%). With respect to the establishment of quotas for high demand programs, the social science department heads indicated that this action was more likely to occur in their discipline area than did the heads in the three other discipline areas $-42 \%$ versus $12 \%$ (engineering and science), $9 \%$ (life sciences), and 6\% (humanities). These data support the propositions referred to earlier (e.g., Hamilton et al., 1991; Yeates, 1991) that the graduate experiences vary considerably across disciplines.

\section{Other Matters}

Several matters other than those described above were explored in the questionnaires. Some of these are presented below, with the information provided by the department heads integrated with the opinions of supervisors.

Years allowed for program The most frequent maximum number of years allowed for a doctoral program was six; for master's programs, four and five years were about equally frequent. Responses of supervisors indicated that they would favor a shorter period: five years was the most frequent choice for a post-bachelor's $\mathrm{PhD}$ program (38\%), four years for a post-master's $\mathrm{PhD}$ program $(37 \%)$, two years for a post-4-years-bachelor's master's program and three years for a post-3-years-bachelor's master's program.

Size of supervisory committee The most common size of supervisory committee for both master's and doctoral students was reported by department heads to be three: $46 \%$ and $48 \%$ identified this number. Supervisors tended to agree that three was the desirable number with $53 \%$ and $37 \%$ choosing three for master's and for doctoral respectively, although $33 \%$ favored four for doctoral committees.

Decider of topic for thesis The current situation in which the topics for both master's and doctoral theses tended to be jointly decided by supervisor and student (75\% master's and $86 \%$ doctoral) was supported by the supervisor respondents (84\% master's and $89 \%$ doctoral). Whereas $19 \%$ of the department heads reported that topics were normally selected by supervisors, only $12 \%$ of supervisors selected this option.

Publication When asked what would be the common situation with respect to authorship of publications resulting from research in which the supervisors had "considerable involvement," $93 \%$ of the department heads identified joint publication by supervisor and student. This position was favored by $87 \%$ of the supervisors. When asked the same question but with "little direct 
involvement," $60 \%$ of the department heads selected the student as the sole author and $33 \%$ selected joint authorship. For supervisors, the responses were $71 \%$ student only and $21 \%$ joint.

Candidacy examination Basing the candidacy examination on both the thesis proposal and course work was reported by $43 \%$ of department heads as the normal situation: such an approach received the support of $40 \%$ of the supervisors. Basing it mainly on the thesis proposal was the second most common practice with $23 \%$ of the department heads selecting this approach: it was supported by $31 \%$ of the supervisors. Only $10 \%$ or fewer favored basing the candidacy examination either solely on the thesis proposal or solely on course work.

\section{General Comments}

The respondents also provided many general comments about the organization and administration of graduate programs. Some of these comments reflected differing opinions, showing that the obtaining of consensus about different issues and practices is unlikely. For example, in one of the universities a respondent recommended that supervisory committees are unnecessary when the supervisor is experienced and successful; others considered that supervisory committees should meet more regularly. Also, while one stated that all graduate theses should be subject to external review, another proposed that graduate programs are restricted by too many rules and regulations. Two professors in that university were especially concerned over the lack of recognition of supervision of graduate students as a part of workload, but most respondents did not address this matter.

\section{Discussion}

Detailed discussion of all of the results of this pilot study cannot be included in this brief article. However, some matters warrant special mention. First, the establishment of quotas in high-demand graduate programs was well favored. Second, meeting the doctoral thesis requirement through a set of interrelated articles in refereed journals was supported by half of the supervisors. Third, respondents placed considerable emphasis upon the importance of the following variables for successful completion of graduate programs student motivation, financial support, supervision, project planning, careful student selection, and a period of full-time study. Fourth, differences in some practices and in the perceived effectiveness of these practices seemed to exist among discipline areas. Some of these findings were consistent with those found in the literature cited in 
the first section of this paper (e.g., variables associated with success) while other findings (e.g., about quotas) are about matters discussed on some campuses but neglected in the literature.

Several other important relevant questions need to be addressed in future research. What major trends in enrolment in master's and doctoral programs in different disciplines are occurring in Canada and in selected other western countries? What are the average completion rates and completion times for graduate programs in different discipline areas? What are the most common ways of incorporating graduate studies into the organizational structure of universities? What linkages exist between the universities' research offices and their faculties/schools of graduate studies? What differences occur in expected and actual supervisory practices among universities, disciplines, and countries? What are the perceived advantages and disadvantages of graduate assistantships? In view of the economic and cultural importance to the nation of graduate studies, and the substantial impact upon individuals' lives of experiences during graduate programs, more detailed examination of this aspect of university operations is certainly warranted.

\section{References}

Boyer, E.L. (1990). Scholarship revisited. Princeton, NJ: The Carnegie Foundation for the Advancement of Teaching.

Bowen, W.G., \& Rudenstine, N.L. (1992). In pursuit of the PhD. Princeton, NJ: Princeton University Press.

Busch, J.W. (1985). Mentoring in graduate schools of education: Mentors' perceptions. American Educational Research Journal, 22(2), 257-265.

Canadian Association of Graduate Schools. (1991). Statistical report 1991. (Prepared by C. Sharpe, Memorial University of Newfoundland.) St. John's, NF: Author.

Christopherson, D. et al. (1983). Research student and supervisor: An approach to good supervisory practice. Swindon, England: Science and Engineering Research Council.

Connell, R. (1985). How to supervise a PhD. The Australian Universities' Review, 28(2), 38-41.

Council of Graduate Schools. (1990). Research student and supervisor. Washington, DC: Author.

Council of Graduate Schools. (1991). The role and nature of the doctoral dissertation. Washington, DC: Author.

Cude, W. (1987). The PhD trap. West Bay, NS: Medicine Label.

Cude, W. (1991). The need for improved doctoral program statistics. The Canadian Journal of Higher Education, 2l(1), 1-12.

Dagg, A.I. (1990). Squeezing out graduate options. University Affairs, 3l(7), 21. 
Dahllöf, U. (1989). Doctoral studies and public policies affecting the labour market for PhDs in Norway and Sweden. Scandinavian Journal of Educational Research, 33(3), 165-184.

Department of the Secretary of State of Canada. (1990). Profile of higher education in Canada. Ottawa, ON: Author.

Economic and Social Research Council. (1989a). Annual Report 1988-89. Swindon, England: Author.

Economic and Social Research Council. (1989b). Discussion paper on research training for the 1990s. Swindon, England: Author.

Economic and Social Research Council. (1991). Postgraduate training: Guidelines. Swindon, England: Author.

Filteau, C. (1989). Proceedings of a conference on women in graduate studies in Ontario. Toronto, ON: Ontario Council on Graduate Studies.

Gordon, R.E., Baker, M., Croft, R.A., D’Arms, J.H. Dimminie, C.B., \& Sheridan, J..D. (1990). Organization and administration of graduate education. Washington, DC: Council of Graduate Schools.

Graduate deans unhappy about time taken to finish degrees. (1988, March). University Affairs, p. 9.

Hamilton, R.G., Baranger, E., Casarett, A.P., Horowitz, F.D., Koenigsknecht, R.A., Lawrence, F.L., Maclachlan, G., Perkins, F.E., \& Traugott, E.C. (1991). The role and nature of the doctoral dissertation. Washington, DC: Council of Graduate Schools.

Healy, D., Dion, C., \& Neatby, B. (1978a). Report of the commission on graduate studies in the humanities and social sciences: Summary. Ottawa, ON: The Canada Council.

Healy, D., Dion, C., \& Neatby, B. (1978b). Report of the commission on graduate studies in the humanities and social sciences. Ottawa, ON: The Canada Council.

Kirkwood, R. (1985). The quest for quality in graduate education. Educational Record, 66(3), 4-8.

Malaney, G.D. (1988). Graduate education as an area of research in the field of higher education. In J. C. Smart (Ed.), Higher education: Handbook of theory and research, Vol. 4 (pp. 397-454). New York: Agathon.

Moses, I. (1985). Supervising postgraduates. Sydney, Australia: Higher Education Research and Development Society of Australasia.

Norris, W. (1989, 26 May). Time up for PhD thesis. The Times Higher Education Supplement, pp. 1 and 11.

Ontario Council on Graduate Studies. (1990). Education: Comments arising from the appraisal of graduate programs in Ontario. Toronto, ON: Council of Ontario Universities.

Organization for Economic Co-operation and Development. (1987). Post-graduate education in the 1980s. Paris: Author.

Palm, R., Baker, M.J., Goldenberg, R.E., Hiiemae, K., Powell, R.E., \& Yeates, M. (1990). Academic review of graduate programs. Washington, DC: Council of Graduate Schools. 
Powles, M. (1986). Chips in the academic wall: Women and postgraduate study. The Australian Universities Review, 29(2), 33-37.

Powles, M. (1988). Know your PhD students and how to help them. Melbourne, Australia: Centre for the Study of Higher Education, University of Melbourne.

Powles, M. (1989). How's the thesis going? Former postgraduates' and their supervisors' views on completion times and dropout. Melbourne, Australia: Centre for the Study of Higher Education, University of Melbourne.

The Royal Society of Canada. (1989). A study of university research in Canada: The issues. Vancouver, BC: Evaluation Research Unit, University of British Columbia.

The Royal Society of Canada. (1991). Realizing the potential: A strategy for university research in Canada. Ottawa, ON: Author.

Smith, A. (1990, May). Postgraduate training: The green paper response. Social Sciences: News from the ESRC (Economic and Social Research Council, Swindon, England), 5:1-8.

Spurr, S.H. (1970). Academic degree structures: Innovative structures. New York: McGraw-Hill.

Stewart, H.B. (1988). The development of graduate studies in Ontario universities between 1960 and 1985. Toronto, ON: Council of Ontario Universities.

Task Force [Canada Council] on Graduate Studies and Research in the Humanities and Social Sciences. (1975). A commitment to excellence. Kingston, ON: Queen's University.

Traugott, E.C., Catania, F.J., Livingston, W.S., Lockhart, M.M., \& Suedfeld, P. (1990). The Doctor of Philosophy degree. Washington, DC: Council of Graduate Schools.

Wilson, E.K. (1987). Department reviews for product improvement in higher education. In J.C. Smart (Ed.), Higher education: Handbook of theory and research, Vol. 3 (pp. 199-241). New York: Agathon.

Winfield, G. (1987a). The social science PhD. London: Economic and Social Research Council.

Winfield, G. (1987b, 27 March). Doctors fighting with an octopus. The Times Higher Education Supplement, p. 15.

Yeates, M. (n.d.) The graduate appraisal process in Ontario. Toronto, ON: Ontario Council on Graduate Studies.

Yeates, M. (1991). Doctoral graduation rates in Ontario universities: A discussion paper. Toronto, ON: Ontario Council on Graduate Studies.

Zwick, R. (1991, April). Factors contributing to persistence in graduate school. Paper presented at annual meeting of the American Educational Research Association, Chicago. 